\title{
Iron Transport in Microalgae: the Isolation and Biological Activity of a Hydroxamate Siderophore from the Blue-Green Alga Agmenellum quadruplicatum
}

\author{
JAMES E. ARMSTRONG* AND CHASE VAN BAALEN \\ University of Texas Marine Science Institute, Port Aransas Marine Laboratory, \\ Port Aransas, Texas 78373, U.S.A.
}

(Received 12 September 1978)

\begin{abstract}
Supernatants from iron-deficient cultures of the marine, coccoid blue-green alga Agmenellum quadruplicatum strain PR-6 contained a chloroform-soluble iron-binding hydroxamate which was stimulatory for the growth of Arthrobacter flavescens JG-9. Production of this material was maximal at $1 \mu \mathrm{M}-\mathrm{Fe}$, was temperature dependent, and was increased by adding $\mathrm{NH}_{4}{ }^{+}$. At the absorption maximum of $430 \mathrm{~nm}$ the $A_{1 \mathrm{~cm}}^{1 \%}$ of the purified ferric complex was 32 . The iron-free compound yielded nitroso dimers on periodate oxidation and was $60 \%$ as active on a weight basis for growth of Arth. flavescens as ferrioxamine B. At concentrations as low as $1 \mathrm{ng} \mathrm{ml}^{-1}$ the purified hydroxamate stimulated growth of iron-depleted Agm. quadruplicatum in a chemically defined medium. Growth factor activity for Arth. flavescens JG-9 was also found in the supernatants and/or cell extracts of other blue-green algae and several diatoms grown under low-iron conditions.
\end{abstract}

\section{INTRODUCTION}

The uptake and transport of iron has long been recognized as a central problem in nutrition. In laboratory cultures of algae, the problem of iron availability has been alleviated by the use of synthetic chelators such as EDTA. For natural populations, however, very little information exists on possible modes of iron uptake and transport (Hutner, 1972). Harvey (1937) proposed that diatoms utilized colloidal particles of ferric hydroxides and phosphates, while Goldberg (1952) concluded that the iron in ferric chelates of citrate, ascorbate and artificial humate was unavailable to the marine diatom Asterionella japonica.

Over the past two decades it has been shown that many micro-organisms produce highaffinity ferric-iron transport compounds. There are two general classes of these microbial ferric-chelating compounds, secondary hydroxamates and catechols, collectively termed siderophores (Lankford, 1973; Neilands, 1973). It can be argued that microalgae, particularly at the alkaline $\mathrm{pH}$ and aerobic conditions in the photic zone, should possess a siderophore-mediated iron uptake system in order to render the insoluble colloidal iron into an available form (Hutner, 1972). However, this particular aspect of algal iron uptake and assimilation has been little investigated (Lankford, 1973).

Siderophore activity has been detected in soil, dung (Neilands, 1973) and various marine ecosystems (Estep et al., 1975). Murphy et al. (1976) suggested that hydroxamate chelators produced by blue-green algae may antagonize growth of other microalgae and hence be a factor in blue-green algal blooms. Recently, Simpson \& Neilands (1976) isolated schizokinen, the dihydroxamate siderophore produced by Bacillus megaterium, from the culture supernatant of iron-starved Anabaena sp.

* Present address: Department of Oceanography, Florida State University, Tallahassee, Florida 32306, U.S.A. 
The purpose of our studies was to examine further the hypothesis that microalgae, in particular the blue-green algae, have a siderophore-mediated iron transport system.

\section{METHODS}

Organisms. The blue-green algae Agmenellum quadruplicatum strains PR-6 and BG-1, Coccochloris elabens strains 17A and Di, Anacystis marina strain WH-20, Lyngbya lagerheimii strain Mont, Oscillatoria williamsii strain Mev, Oscillatoria sp. strain JCM, Microcoleus chthonoplastes strain Ba-1, Plectonema terebrans strain Cal SP-31, Schizothrix calcicola strain Man and an unidentified filamentous form (strain A-2), and the diatoms Amphora sp. strain Amp and Cylindrotheca sp. strain N-1 are marine isolates of this laboratory (Van Baalen, 1962; Morgan, 1975). The green algae Chlorella autotrophica strain Indiana 580 and Dunaliella tertiolecta strain Dun were obtained from Dr R. R. L. Gulliard of the Woods Hole Marine Laboratory, U.S.A; and Chlorella sorokiniana strain Tx 7-11-05, Chlorella ellipsoidea and Chlorella pyrenoidosa were from Dr Jack Myers of the Laboratory of Algal Physiology, the University of Texas at Austin, U.S.A. The siderophore auxotroph Arthrobacter flavescens JG-9 was obtained from Dr C. E. Lankford, Department of Microbiology, The University of Texas at Austin, U.S.A.

Culture media and procedures. Marine isolates were grown in medium ASP-2 (Provasoli et al., 1957) as modified by Van Baalen (1962), with various deletions or supplements as noted in the text. ASP-2 basal medium contained $\left(\mathrm{g} \mathrm{l}^{-1}\right): \mathrm{NaCl}, 18 ; \mathrm{MgSO}_{4} .7 \mathrm{H}_{2} \mathrm{O}, 5 \cdot 0 ; \mathrm{KH}_{2} \mathrm{PO}_{4}, 0.05 ; \mathrm{CaCl}_{2} .2 \mathrm{H}_{2} \mathrm{O}, 0.37 ; \mathrm{KCl}, 0 \cdot 60$; $\mathrm{NaNO}_{3}, 1 \cdot 0 ; \mathrm{FeCl}_{3} .6 \mathrm{H}_{2} \mathrm{O}, 0.004 ; \mathrm{Na}_{2}$ EDTA. $2 \mathrm{H}_{2} \mathrm{O}, 0.03$; Tris, $1 \cdot 0$; and $10 \mathrm{ml} \mathrm{P}-1$ trace metals stock solution containing (mg 1-1): $\mathrm{H}_{3} \mathrm{BO}_{3}, 3426 ; \mathrm{MnCl}_{2} .4 \mathrm{H}_{2} \mathrm{O}, 432 ; \mathrm{ZnCl}_{2}, 31 \cdot 5 ; \mathrm{MoO}_{3}(85 \%), 3 \cdot 0 ; \mathrm{CuSO}_{4} \cdot 5 \mathrm{H}_{2} \mathrm{O}, 0 \cdot 3$; $\mathrm{CoCl}_{2} .6 \mathrm{H}_{2} \mathrm{O}, 1 \cdot 2$. Where indicated, vitamin $\mathrm{B}_{12}$ was added at $4 \mu \mathrm{gl}^{-1}$ and vitamin $\mathrm{B}_{1}$ at $1 \mathrm{mg}{ }^{-1}$. Chlorella sorokiniana, Chl. ellipsoidea, Chl.pyrenoidosa were cultured either in medium C of Kratz \& Myers (1955), or in medium Cg-10 of Van Baalen (1967), or in medium Ct-10, i.e. medium Cg-10 with Tris buffer instead of glycylglycine buffer. Stock cultures were carried on the appropriate medium solidified with $1 \%$ agar (Difco 0140) and incubated under fluorescent or tungsten lamps at room temperature (22 to $25^{\circ} \mathrm{C}$ ).

The algae were grown in liquid culture at various temperatures using the test tube method of Myers (1950). Illumination was provided by four F24T12CW/HO or F48T12CW/XHO fluorescent lamps, two on each side of the water bath, $8 \mathrm{~cm}$ from the $22 \times 175 \mathrm{~mm}$ Pyrex growth tubes. Air enriched to $1 \cdot 0 \pm 0 \cdot 1 \%(\mathrm{v} / \mathrm{v}) \mathrm{CO}_{2}$ was continuously bubbled through the cultures.

Contaminating iron in the ASP-2 medium without added iron was decreased by filtering the medium through Seitz filters (Arthur H. Thomas Co., Philadelphia, Pa, U.S.A; No. 4580) previously washed with $3 \mathrm{M}-\mathrm{HCl}$ and rinsed with deionized distilled water (Kurowski \& Pirt, 1971). These media are designated SF in the text and, unless otherwise indicated, EDTA and iron were not added.

Growth was occasionally monitored by chlorophyll $a$ content [determined in $80 \%$ (v/v) acetone extracts using $82.04 \mathrm{~cm}^{2} \mathrm{mg}^{-1}$ as the absorption coefficient at $663 \mathrm{~mm}$ (MacKinney, 1941)] but more usually by turbidimetry using a colorimeter with a coloured glass filter $(660 \mathrm{~nm})$. Specific growth rates $(k)$ are reported in $\log _{10}$ units $\mathrm{d}^{-1}$; when $k=0.301 \mathrm{~d}^{-1}$ the doubling time is $24 \mathrm{~h}$. The packed cell volume of appropriate cell suspensions were determined after centrifuging for $2 \mathrm{~h}$ at $2800 \mathrm{~g}$ in cell volume tubes (Bellco Glass Co., Vineland, N.J., U.S.A; no. T-442).

Isolation of Agm.quadruplicatum PR-6 siderophore. Cells grown through two transfers in complete ASP-2+ $\mathrm{B}_{12}$ medium and washed three times with ASP-2 SF medium (minus Fe, minus EDTA) were inoculated at $2.5 \times 10^{6}$ cells ml ${ }^{-1}$ into the siderophore production medium [ASP-2 $+\mathrm{B}_{12}$, minus $\mathrm{Fe}\left(0.5 \mu \mathrm{g}\right.$ residual $\left.\mathrm{Fe} \mathrm{ml}{ }^{-1}\right)$, minus EDTA, one-tenth of the normal concentration of $\mathrm{P}-1$ trace metals, plus $3 \mathrm{mM}-\mathrm{NH}_{4} \mathrm{Cl}$ ] and incubated for $48 \mathrm{~h}$ at $30^{\circ} \mathrm{C}$. (Careful washing of the inoculum was required for maximum siderophore production as any EDTA carried over repressed siderophore biosynthesis.) Cells were removed from the culture fluid by centrifugation; $\mathrm{FeCl}_{3}$ in $0 \cdot 1 \mathrm{M}-\mathrm{HCl}$ was added to the supernatant and the $\mathrm{pH}$ was adjusted to 4.5 with concentrated $\mathrm{HCl}$. The iron-saturated supernatant was extracted three times with $0.5 \mathrm{vol}$. redistilled chloroform, which removed essentially all of the ferric-reactive material and Arth. flavescens JG-9 growth factor activity from the aqueous phase. The chloroform extract was evaporated to near dryness at $39^{\circ} \mathrm{C}$ in a vacuum rotary evaporator. The residue was redissolved in $1.0 \mathrm{ml}$ chloroform/ethanol $(1: 1, \mathrm{v} / \mathrm{v})$, applied to a $1.5 \times$ $15 \mathrm{~cm}$ column of Sephadex LH-20, and eluted with the chloroform/ethanol mixture. A brick-red band, containing the Arth. flavescens JG-9 growth factor activity was eluted first, followed by several bands detectable by their yellowish colour or their fluorescence under $365 \mathrm{~nm}$ light. None of the bands gave a positive reaction with Arnow's reagent for catechols.

Biological assays. Arthrobacter favescens JG-9 basal medium and the bioassay for siderophore growth factor activity of algal supernatants and cell extracts were as reported previously (Estep et al., 1975). Algal cells were extracted using a slight modification of the method of Byers et al. (1967). Frozen cells were sus- 
pended in $95 \%(\mathrm{v} / \mathrm{v})$ ethanol, and the mixture was heated to near boiling point and allowed to stand for 2 to $3 \mathrm{~h}$ with periodic stirring. After cell debris had settled, the extract was filtered through $0.4 \mu \mathrm{m}$ pore-size membrane filters. Fresh water algal strains were tested by streaking dense suspensions on Arth. flavescens JG-9 lawns.

Viability (colony-forming units) of iron-depleted $\mathrm{Agm}$. quadruplicatum PR-6 was determined using the single cell plating techniques of Van Baalen $(1965,1967)$.

For preparation of the iron-depleted inoculum, a loopful from a 7 to $14 \mathrm{~d}$ slant culture was transferred into basal medium ASP-2 $+B_{12}$ and grown through two successive transfers to about $1 \times 10^{7}$ cells $\mathrm{ml}^{-1}$. The cells were then harvested and washed with medium ASP-2 SF (minus Fe, minus EDTA, minus P-1 trace metals) by centrifuging and resuspension in three successive changes of the wash medium. The washed cells were resuspended in ASP-2 $+\mathrm{B}_{12}$ SF (minus Fe, minus EDTA, one-tenth of the normal concentration of $\mathrm{P}-1$ trace metals), diluted to $4.75 \times 10^{5}$ cells $\mathrm{ml}^{-1}$ and incubated at $39^{\circ} \mathrm{C}$. After $24 \mathrm{~h}$ incubation, the cells $\left(0.52 \times 10^{7}\right.$ to $\left.0.57 \times 10^{7} \mathrm{ml}^{-1}\right)$ were harvested, washed three times with ASP-2 SF (minus Fe, minus EDTA, minus P-1 trace metals) and diluted to give 2000 cells $\mathrm{ml}^{-1}$. The bioassay medium for recovery from iron deficiency, developed during the course of this work, was: ASP-2+ $\mathrm{B}_{12}$ SF (minus EDTA, minus P-1 metals) with $\mathrm{FeCl}_{2} .6 \mathrm{H}_{2} 0$ added to give $0.2 \mathrm{Fe} \mu \mathrm{g} \mathrm{ml}^{-1}$ and $\mathrm{MnCl}_{2} \cdot 4 \mathrm{H}_{2} \mathrm{O}$ added at $1.73 \mu \mathrm{g} \mathrm{ml}^{-1}$ prior to autoclaving for 15 min at $121^{\circ} \mathrm{C}$. The iron-depleted, washed inoculum was mixed in a large volume of the bioassay medium and dispensed in $20 \mathrm{ml}$ samples to pre-sterilized growth tubes containing the siderophore isolated from Agm. quadruplicatum PR-6 (1 to $200 \mathrm{ng} \mathrm{ml}^{-1}$ ) or other test compound.

Various compounds were assayed for growth stimulating activity on algal lawns (2000 cells $\mathrm{ml}^{-1}$ ) prepared using iron-depleted, washed cells suspended in ASP-2 $+\mathrm{B}_{12}$ SF (minus EDTA, $0 \cdot 2 \mathrm{~g} \mathrm{Fe} \mathrm{ml}^{-1}$, $0.4 \mu \mathrm{g} \mathrm{MnCl}_{2} .4 \mathrm{H}_{2} \mathrm{O} \mathrm{ml}-1,1 \mathrm{mM}-\mathrm{NH}_{4} \mathrm{Cl}$ ) solidified with $1 \%(\mathrm{w} / \mathrm{v})$ agar (Difco 0140) washed in distilled water. Aqueous solutions of the chelating compounds were filter-sterilized and absorbed into water-washed sterile $13 \mathrm{~mm}$ diam. filter paper discs (Schleicher \& Schuell, no. 740-E) which were then placed on the algal lawns. After incubation for 4 to $5 \mathrm{~d}$ at $32^{\circ} \mathrm{C}$ under tungsten lights, the plates were examined under a dissecting microscope.

All glassware was routinely soaked in 3 to $5 \mathrm{M}-\mathrm{HCl}$ for 12 to $14 \mathrm{~h}$ to remove contaminating iron deposits and rinsed with distilled water a minimum of seven times.

Chemical assays. Algal cellular iron content was assayed using ferrozine (Stookey, 1970) or bathophenanthroline sulphonate, sodium salt (Diehl et al., 1965) as chromogenic reagents. Cell material was wet ashed in $2.0 \mathrm{ml}$ of concentrated acid mixture $\left(\mathrm{HNO}_{3} / \mathrm{H}_{2} \mathrm{SO}_{4} / \mathrm{HClO}_{4} ; 10: 1: 4\right.$, by vol.) in $30 \mathrm{ml}$ Corex centrifuge tubes heated on a modified Kjeldahl digestion apparatus. Blanks and iron standards (iron wire in $0 \cdot 1 \mathrm{M}-$ $\left.\mathrm{HNO}_{3}\right)$ were similarly processed and the amount of iron in the blank $(0.8$ to $1.0 \mu \mathrm{g})$ was subtracted from the results for the test solutions. Absorbance was measured at $562 \mathrm{~nm}$ or $535 \mathrm{~nm}$ respectively, for the two reagents.

Bound hydroxylamine was assayed by the method of Csaky (1948) as modified by Gibson \& Magrath (1969). The assay, however, is not quantitative and recovery of hydroxylamine may be variable (Byers et al., 1967). Hydroxylamine (assayed without acid digestion), sodium nitrite, and ferrioxamine $B$ hydrochloride (prepared by adding $\mathrm{FeCl}_{3} \cdot \mathrm{H}_{2} \mathrm{O}$ to Desferal in aqueous solutions) were used as standards. The absorbance of the diazo-coupled product was measured at $563 \mathrm{~nm}$.

Cultures and culture supernatants were tested for dihydroxyphenolic compounds with Arnow's reagent (Arnow, 1937) using catechol and 2,3-dihydroxybenzoic acid as standards. The absorbancy of the test solutions was measured at $510 \mathrm{~nm}$.

Chemicals. Samples of ferrichrome and rhodotorulic acid were generously supplied by Professor J. B. Neilands, Department of Biochemistry, University of California at Berkeley, U.S.A. Desferal (desferrioxamine B mesylate) was obtained from Ciba-Geigy Chemical Co., Summit, N.J., U.S.A.

\section{RESULTS}

\section{Survey of microalgae for siderophore activity}

In preliminary studies, culture supernatants and cells of Agm. quadruplicatum strains PR-6 and BG-1 and Coccochloris elabens strains Di and 17A after growth on iron-limited medium were assayed for hydroxamate siderophores. Growth factor activity for Arth. flavescens JG-9 was found but was variable and not dependent on the iron concentration of the medium. Csaky tests for bound hydroxylamine, performed on the algal supernatants which stimulated Arth. flavescens JG-9, were positive but very low. Subsequently, ironsufficient cells of Agm. quadruplicatum PR-6 grown in medium ASP-2 $+\mathrm{B}_{12}$ were extracted 
Table 1. Survey of microalgae for siderophore production: growth stimulation of Arthrobacter flavescens JG-9 and the Csaky reaction

Microalgal strain* $\overbrace{\begin{array}{c}\text { Culture } \\ \text { supernatant }\end{array}}^{\text {JG-9 pad assay }} \begin{gathered}\begin{array}{c}\text { Ethanol } \\ \text { cell extract }\end{array} \\ \begin{array}{c}\text { Culture } \\ \text { supernatant }\end{array}\end{gathered}$

Blue-green algae

Agmenellum quadruplicatum PR-6

Agmenellum quadruplicatum BG-1

Anacystis marina WH-20

Coccochloris elabens 17A

Coccochloris elabens Di

Microcoleus chthonoplastes $\mathrm{Ba}-1$

Lyngbya lagerheimii Mont

Plectonema terebrans Cal SP-31

Oscillatoria williamsii $\mathrm{Mev}$

Oscillatoria sp. JCM

Schizothrix calcicola Man

Unidentified species A-2

Green algae

Dunaliella tertiolecta Dun

Chlorella autotrophica Ind 580

Diatoms

Amphora sp. Amp

Cylindrotheca $\mathrm{sp} . \mathrm{N}-1$

\begin{tabular}{|c|c|c|}
\hline+ & + & + \\
\hline- & + & - \\
\hline- & - & - \\
\hline+ & + & + \\
\hline- & + & - \\
\hline- & + & - \\
\hline- & - & - \\
\hline- & - & - \\
\hline- & + & - \\
\hline- & + & - \\
\hline- & + & - \\
\hline- & + & - \\
\hline- & - & - \\
\hline- & - & - \\
\hline- & + & - \\
\hline$-\dagger t$ & $+\ddagger$ & - \\
\hline
\end{tabular}

* All strains were cultured at $30^{\circ} \mathrm{C}$ in medium ASP-2+vitamins $\mathrm{B}_{1}$ and $\mathrm{B}_{12}$ (minus Fe, minus EDTA, plus $50 \mathrm{mg} \mathrm{NH}_{4} \mathrm{Cl} \mathrm{l}^{-1}$, one-tenth of the normal concentration of P-1 trace metals). For growth of the diatoms, the medium was supplemented with $125 \mathrm{mg} \mathrm{Na} \mathrm{SiO}_{3} .5 \mathrm{H}_{2} \mathrm{Ol}^{-1}$.

$\dagger$ Chloroform extract of culture supernatant concentrated 1000 -fold.

$\ddagger$ Zone of inhibition of background growth around pad immediately followed by a zone of stimulation.

with methanol, ethanol, acetone, $85 \%$ (w/v) phenol, chloroform and several combinations of these solvents in a Soxhlet apparatus. Siderophore growth factor activity was best recovered using chloroform extraction for $24 \mathrm{~h}$. When the chloroform extract was evaporated to $5.0 \mathrm{ml}$ and assayed for growth factor activity for Arth. flavescens JG-9, the extract gave a growth stimulatory effect equivalent to about $0.7 \mu \mathrm{g}$ Desferal (g dry wt algae) ${ }^{-1}$. This material gave a positive Csaky test for bound hydroxylamine. By comparison, Byers et al. (1967) found Bacillus megaterium contained $400 \mu \mathrm{g}$ schizokinen ( $\mathrm{g}$ dry wt) ${ }^{-1}$ when grown in iron-sufficient medium without a synthetic metal chelator.

Siderophore activity was recovered from a variety of blue-green algae and diatoms when grown on low-iron medium (Table 1). Supernatants were tested directly, except that of Cylindrotheca sp. strain $\mathrm{N}-1$ which was a 1000 -fold concentrated chloroform extract. The freshwater algae Chl. pyrenoidosa, Chl. ellipsoidea and Chl. sorokiniana gave a positive response only when streaked on JG-9 lawns. Supernatants of Agm. quadruplicatum PR-6 yielded the highest siderophore activity, equivalent to $1 \mu \mathrm{g}$ Desferal $\mathrm{ml}^{-1}$.

In a survey of specific growth rates and yield of cells in low-iron media without added EDTA, Agm. quadruplicatum PR-6 was clearly superior to Coccochloris elabens strains Di and 17A and Agm. quadruplicatum strain BG-1. It grew reproducibly in medium ASP-2 + $\mathrm{B}_{12}$ without EDTA at $80 \%$ of the rate in medium containing EDTA. The cell yield (dry wt $\mathrm{ml}^{-1}$ ) for any given limiting amount of iron was nearly twice that of the other three organisms. Iron added at $0 \cdot 1 \mu \mathrm{g} \mathrm{Fe} \mathrm{ml}^{-1}$ to ASP-2 medium minus EDTA gave a maximum growth rate and biomass production after $72 \mathrm{~h}$. This alga was therefore selected for further study. 


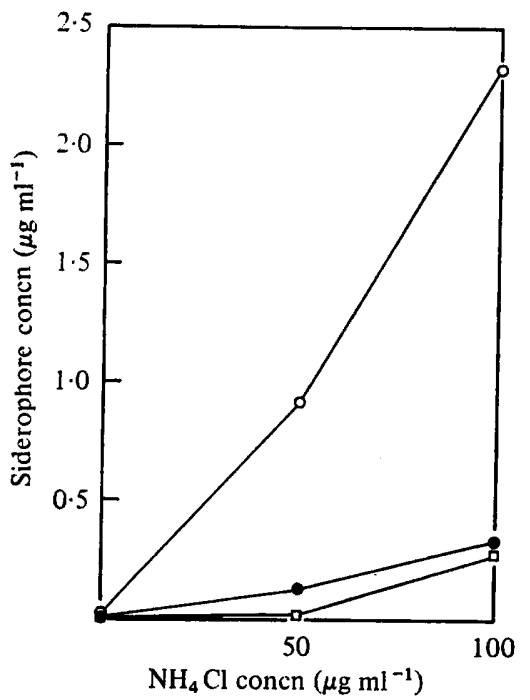

Fig. 1

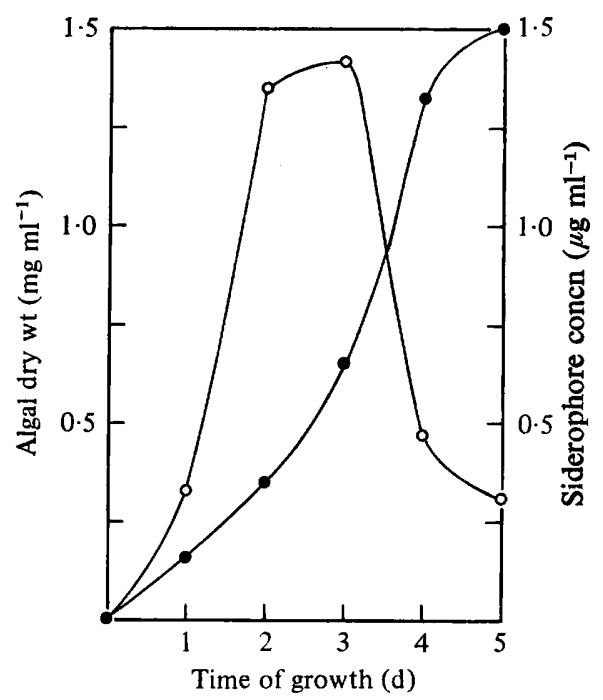

Fig. 2

Fig. 1. Arthrobacter flavescens JG-9 growth factor activity in supernatants of iron-depleted Agmenellum quadruplicatum PR-6 as a function of the temperature and $\mathrm{NH}_{4} \mathrm{Cl}$ concentration. The PR-6 inoculum was grown at $30^{\circ} \mathrm{C}$ in complete ASP- $2+\mathrm{B}_{12}$ medium, washed three times with ASP-2 SF (minus $\mathrm{Fe}$ ), resuspended in ASP-2 $+\mathrm{B}_{12}$ (minus Fe, minus EDTA, one-tenth of the normal concentration of P-1 trace metals, plus $\mathrm{NH}_{4} \mathrm{Cl}$ as indicated) at an initial cell density of about $0.25 \times 10^{7}$ cells $\mathrm{ml}^{-1}$, and incubated at $26^{\circ} \mathrm{C}(\bullet), 30^{\circ} \mathrm{C} \mathrm{(O)}$ or $39^{\circ} \mathrm{C}(\square)$ for $48 \mathrm{~h}$. Siderophore activities of algal supernatants are expressed as Desferal equivalents.

Fig. 2. Time course of Agmenellum quadruplicatum PR-6 growth and siderophore production. The PR-6 inoculum was grown and prepared as in Fig. 1 . The initial cell density was about $0.5 \times 10^{7}$ cells $\mathrm{ml}^{-1}$, cultures were incubated at $30^{\circ} \mathrm{C}$, and $1 \mathrm{~mm}-\mathrm{NH}_{4} \mathrm{Cl}$ was added to the basal medium. Cultures were taken at intervals for estimations of siderophore concentration $(O$, expressed as Desferal equivalents) and algal dry weight (๑).

\section{Isolation and properties of the siderophore from Agm. quadruplicatum PR-6}

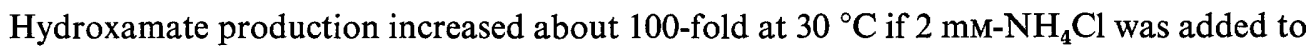
the medium, but there was only a slight increase if cultures were incubated at 26 or $39^{\circ} \mathrm{C}$ (Fig. 1). Accumulated siderophore activity was maximal about $48 \mathrm{~h}$ after the beginning of iron depletion (Fig. 2).

A sufficient quantity of the Agm. quadruplicatum PR-6 siderophore for chemical and biological assays was obtained by scaling up cultures to $250 \mathrm{ml}$ in $50 \times 500 \mathrm{~mm}$ culture tubes. The siderophore was isolated as described in Methods. The major fraction following elution from Sephadex LH-20 with chloroform/ethanol $(1: 1, \mathrm{v} / \mathrm{v})$ was evaporated under nitrogen and dissolved in a minimum volume of $0.02 \mathrm{M}$-ammonium formate, $\mathrm{pH}$ 9:0. When this sample was passed through a $1.5 \times 20 \mathrm{~cm}$ column of Sephadex G-25 and eluted with $0.02 \mathrm{M}$-ammonium formate, $\mathrm{pH} 9.0$, it was separated into a major and a minor band. Both bands had qualitatively identical ultraviolet and visible absorption spectra and growth factor activity. The minor band was not investigated further. When the major band was rechromatographed on Sephadex G-25, it moved as a single band. Ammonium salts were removed by adjusting the eluate $\mathrm{pH}$ to 4.5 and extracting the ferric hydroxamate into chloroform. A typical yield was 2.0 to $2.5 \mathrm{mg}$ of purified compound per litre of culture supernatant.

The ferric compound was soluble in chloroform, butan-2-ol, ethanol and methanol. It was only sparingly soluble in acetone and was insoluble in diethyl ether. The solubility in aqueous solutions was increased considerably above $\mathrm{pH} 8 \cdot 0$. 


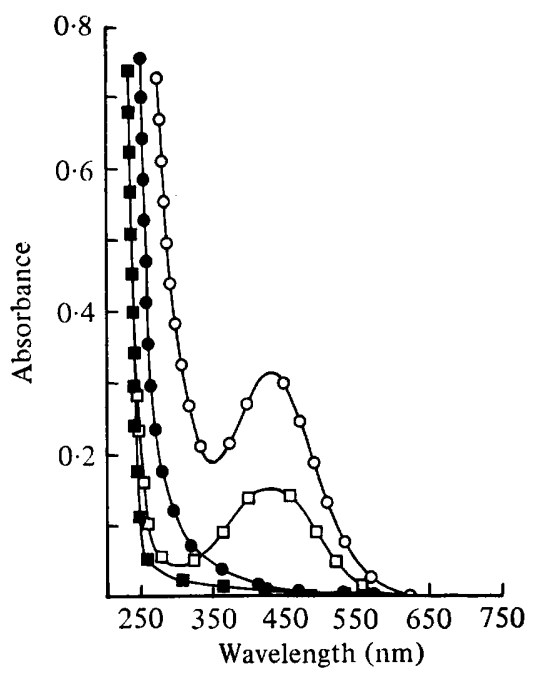

Fig. 3. Absorption spectra of the Agmenellum quadruplicatum PR-6 siderophore $(\bigcirc)$ and PR-6 desferrisiderophore (O) in chloroform. Shown for comparison are spectra of ferrioxamine B ( $\square$ ) and desferrioxamine $\mathbf{B}(\boldsymbol{\square})$ in water.

The absorption spectrum of the purified compound in chloroform had a broad absorption peak at $430 \mathrm{~nm}$, typical of ferric hydroxamates (Fig. 3). The $A_{1 \mathrm{~cm}}^{1 \%}$ in chloroform was 32, which is in the general range reported for ferric hydroxamates (Neilands, 1966). There were only small changes in absorbance with $\mathrm{pH}$ change (2.0 to 9.5$)$ suggesting that the compound is a trihydroxamate, although a dihydroxamate with another strong complexing group cannot be ruled out (Byers et al., 1967; Emery, 1965; Gibson \& Magrath, 1969).

Iron was removed from the ferric complex by shaking the chloroform solution with $5 \mathrm{M}-\mathrm{HCl}$ followed by washing the chloroform twice with distilled water [this is essentially the method used by Snow (1965) to remove iron from mycobactin].

Periodate oxidation of $0.1 \mathrm{mg}$ of the desferrihydroxamate by the method of Emery \& Neilands $(1960,1962)$ gave a product with an absorption peak at $267 \mathrm{~nm}$. The intact desferrisiderophore had no absorption peak near this wavelength at the same concentration. Oxidation of Desferal with periodate under the same conditions gave an apparent molar absorption of 8810 . This value is less than the theoretical yield for nitrosoalkane dimers from Desferal but is in good agreement with values obtained with other polyhydroxamic acids (Atkin \& Neilands, 1968; Gibson \& Magrath, 1969).

The hydroxylamine content of the siderophore was estimated by the method of Csaky (1948) following the acid hydrolysis procedure of Gibson \& Magrath (1969); 0.231 mg siderophore gave an absorbance of 0.66 . This compares with $0 \cdot 1 \mu \mathrm{mol}$ sodium nitrite and hydroxylamine standards which gave an absorbance of 0.438 when assayed without acid and $0.055 \mathrm{mg}$ ferrioxamine $\mathrm{B}$, prepared by adding iron to Desferal, which gave an absorbance of $0 \cdot 38$.

Despite the lack of strict quantification, these chemical assays support the conclusion that the Agm. quadruplicatum PR-6 siderophore is probably a trihydroxamate.

The iron content of siderophore, estimated by extracting a chloroform solution (containing $11.82 \mathrm{mg}$ ) with $5 \mathrm{M}-\mathrm{HCl}$ (Snow, 1965) and quantifying the iron with ferrozine (Stookey, 1970), was about $4 \%(w / w)$. From this value a molecular weight can be calculated for the iron complex as 1300, assuming a $1: 1$ binding ratio. This then gives a molar absorption of about 4100 which accords with the previously recorded value of 3000 to 4000 for ferric polyhydroxamic acids (Neilands, 1966, 1973). 


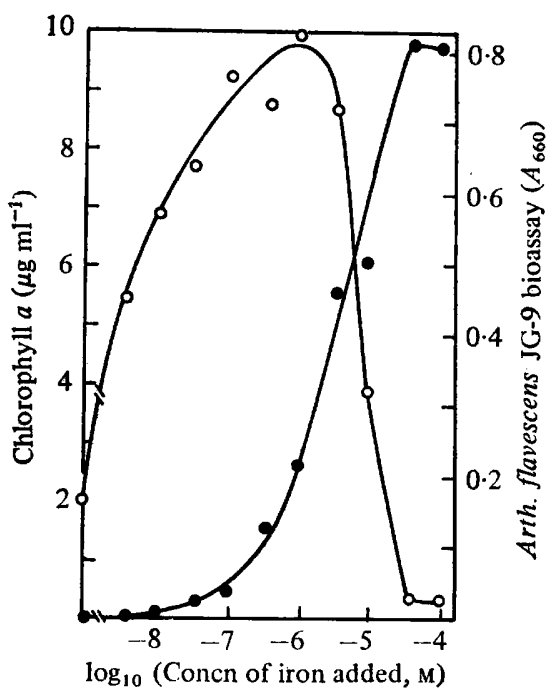

Fig. 4

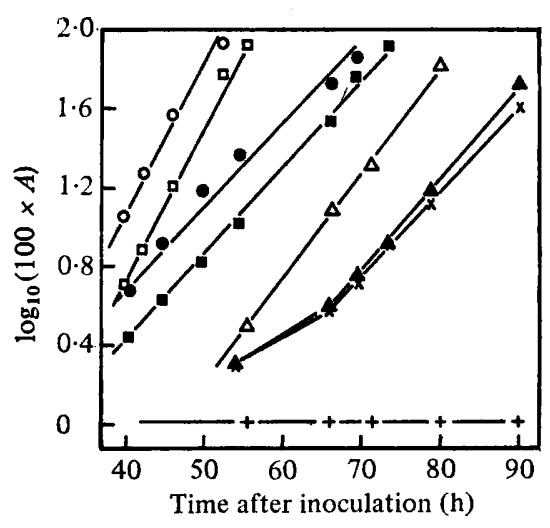

Fig. 5

Fig. 4. Growth of Agmenellum quadruplicatum PR-6 and excretion of Arthrobacter flavescens JG-9 growth factor activity as a function of the initial iron concentration. The PR-6 inoculum was grown and prepared as in Table 1 and resuspended in ASP- $2+B_{12}$ SF (Fe added as indicated, minus EDTA,

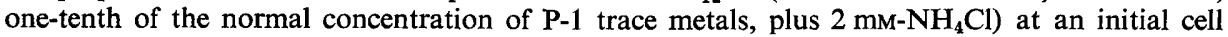
density of about $0.3 \times 10^{6}$ cells ml-1. Cultures were incubated at $30^{\circ} \mathrm{C}$ for $48 \mathrm{~h}$. Algal supernatant siderophore concentration (O) was estimated turbidimetrically $\left(A_{660}\right)$ in liquid culture Arth. flavescens JG-9 assay and growth (๑) was determined as chlorophyll $a$ concentration.

Fig. 5. Effect of Agmenellum quadruplicatum PR-6 siderophore and trace metal concentration on the growth of iron-depleted, washed PR-6 cells. Iron-depleted, washed cells were incubated at $39^{\circ} \mathrm{Cin}$ medium containing $0.2 \mu \mathrm{g} \mathrm{Fe} \mathrm{ml}^{-1}$ and four-tenths of the normal concentration of $\mathrm{Mn}^{2+}$ (no other P-1 trace metals) with purified PR-6 siderophore added at $10(\bigcirc), 5(\square), 1(\triangle)$ and $0(+) \mathrm{ng} \mathrm{ml}^{-1}$ or four-tenths of the normal concentration of P-1 trace metals with PR-6 siderophore added at

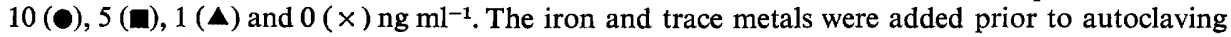
and no $\mathrm{NH}_{4} \mathrm{Cl}$ was added to the bioassay medium.

\section{Biological features of the Agm. quadruplicatum siderophore}

The specific growth factor activity of the purified siderophore for Arth. flavescens JG-9 was estimated by plate and liquid culture bioassays to be about $60 \%$ of an equivalent weight of ferrioxamine $\mathbf{B}$.

Iron added to Agm. quadruplicatum PR-6 cultures repressed siderophore production (Fig. 4). Excretion of siderophore activity was maximal with added iron at $1 \mu \mathrm{M}$ and was completely repressed at $50 \mu \mathrm{M}$-iron. This behaviour is typical of siderophore repression in various microbial systems (Lankford, 1973; Neilands, 1973).

Agmenellum quadruplicatum PR-6 grown in basal medium ASP-2 $+\mathrm{B}_{12}$, washed three times with ASP-2 SF (minus Fe, minus EDTA, minus P-1 metals), then depleted of iron for $24 \mathrm{~h}$ at $39^{\circ} \mathrm{C}$ in medium ASP-2 $+\mathrm{B}_{12} \mathrm{SF}$ (minus Fe, minus EDTA, one-tenth of the normal concentration of P-1 trace metals), exhibited a lag of 10 to $12 \mathrm{~h}$ in recovering to the normal generation time of $4 \mathrm{~h}$ in medium minus EDTA, but containing $2 \mu \mathrm{M}-\mathrm{Fe}$. Adding the purified siderophore at $0.10 \mu \mathrm{g} \mathrm{ml}^{-1}$ decreased this lag period by 1.5 to $2.0 \mathrm{~h}$ but the effect was not dependent on the initial cell concentration over the range tested $\left(1.6 \times 10^{5}\right.$ to $40 \times 10^{5}$ cells $\mathrm{ml}^{-1}$ ). A siderophore-dependent lag in growth initiation from small cell inocula seen in some bacterial systems (Lankford et al., 1966) could not be demonstrated in Agm. quadruplicatum PR-6.

Two conditions which strongly inhibit the rate of recovery from iron deficiency were (i) vigorous washing via vortex mixing of the iron-deficient cells used as inocula, and (ii) autoclaving added iron with the medium. Under these conditions recovery from iron deficiency 
was largely dependent on added siderophore (Fig. 5). Although maximum siderophore stimulation varied, sometimes occurring at 10,5 or even $1 \mathrm{ng} \mathrm{ml}^{-1}$, the results were qualitatively similar: adding the purified siderophore to iron-deficient cells always resulted in more rapid recovery. Concentrations of the isolated siderophore higher than $10 \mathrm{ng} \mathrm{ml}^{-1}$ gave no greater stimulation and appeared to inhibit recovery in a few cases. Iron-deficient, washed cells did not grow unless $\mathrm{FeCl}_{3}$ was added to the bioassay medium. Manganase was also required for recovery from iron deficiency as no growth occurred if manganese was omitted from the bioassay medium. Trace metal interactions may be an explanation for some of the difficulty in experimental control.

Other compounds were assayed for growth stimulating activity using algal lawns of Agm. quadruplicatum PR-6. Rhodotorulic acid, 2,3-dihydroxybenzoic acid, acetylacetone and 8-hydroxyquinoline were inhibitory with no stimulation beyond the zone of complete inhibition. Growth was stimulated by acetohydroxamic acid, sodium citrate, oxalic acid, lactic acid, salicylic acid, kojic acid, ferrichrome Desferal and the purified Agm. quadruplicatum PR-6 siderophore as estimated by visual and microscopic comparison of colony size and colony colour against the control pads.

\section{DISCUSSION}

Iron repression of biosynthesis, grown factor activity for Arth. flavescens JG-9, and a positive Csaky test for bound hydroxylamine may be considered sufficient evidence that Agm. quadruplicatum PR-6 produces a hydroxamate siderophore and thus has an iron transport system of the type common to most aerobic micro-organisms. Detection of growth factor activity for Arth. flavescens JG-9 in some of the blue-green algae, diatoms and green algae surveyed suggests that microalgae as a whole may produce iron-repressible ferriccomplexing compounds under the appropriate conditions of low-iron availability (Simpson \& Neilands, 1976; Murphy et al., 1976).

The purified siderophore from Agm.quadruplicatum PR-6 is unusual in that it is extractable from aqueous media into chloroform, a property in common with the recently discovered exochelin excreted by Mycobacterium bovis (Macham \& Ratledge, 1975). A trihydroxamate siderophore is possibly indicated by the small spectral changes of the iron complex at different $\mathrm{pH}$ values. Nitroso dimer generation via periodate oxidation indicates the compound contains secondary hydroxamate groups.

Evidence that the hydroxamatefunctions as a siderophore is the derepression of biosynthesis by iron depletion and the stimulatory activity in recovery of Agm. quadruplicatum PR-6 from iron deficiency. Iron-deficient cells exhibited a growth response to the isolated siderophore at concentrations of $1 \mathrm{ng} \mathrm{ml}^{-1}$, and $5 \mathrm{ng} \mathrm{ml}^{-1}$ was sufficient to saturate growth. Phytoplankton samples have been found to excrete 7 to $50 \%$ of photoassimilated carbon (Fogg et al., 1965) and excretion of nitrogenous substances, chiefly amino acids and small peptides, is reported to be common in algal cultures (Walsby, 1974; Hellebust, 1974). Such excretion was, in general, thought to be the result of an imbalance between metabolic pathways. Hood et al. (1969) suggested that release of extracellular peptides and amino acids by Anabaena variabilis was due to lack of metabolic control over amino acid biosynthesis. Siderophore excretion and recovery from iron deficiency by Agm. quadruplicatum PR-6 indicates a high degree of metabolic control over iron-assimilatory mechanisms and iron-dependent metabolic pathways. Excretion of organic compounds, especially nitrogenous substances, by phytoplankton may be a reflection of a similar iron-uptake mechanism. The subtle influence that siderophores, having both growth stimulatory and inhibitory activity, may play in microalgal species succession and diversity has been pointed out (Hutner, 1972). 
We are grateful for the expert technical assistance of Mrs Rita O'Donnell, University of Texas Marine Science Institute Contribution No. 313.

\section{REFERENCES}

ARnow, L. F. (1937). Colorimetric determination of the components of 3,4-dihydroxyphenylalaninetyrosine mixtures. Journal of Biological Chemistry 118, 531-537

Atkin, C. L. \& Neilands, J. B. (1968). Rhodotorulic acid; a diketopiperazine dihydroxamic acid with growth-factor activity. I. Isolation and characterization. Biochemistry 7, 3734-3739.

Byers, R. B., Powell, M. V. \& Lankford, C. E. (1967). Iron-chelating hydroxamic acid (schizokinen) active in initiation of cell division of Bacillus megaterium. Journal of Bacteriology 93, 286-294.

CSAKY, T. Z. (1948). On the estimation of bound hydroxylamine in biological materials. Acta chemica scandinavica 2, 450-454.

Diehl, H., Smith, G. F., McBride, L, \& CryberG, R. (1965). The Iron Reagents: Bathophenanthroline Disulfonic Acid,2,4,6-Tripyridyl-S-triazine, Phenyl2-pyridyl Ketoxime, 2nd edn. Columbus, Ohio: The G. Frederick Smith Chemical Co.

EMERY, T. F. (1965) Isolation, characterization, and properties of fusarine, a $\delta$-hydroxamic acid derivative of ornithine. Biochemisrty 4, 14101417.

Emery, T. F. \& Nellands, J. B. (1960). Periodate oxidation of hydroxylamine derivatives. Products, scope, and application. Journal of the American Chemical Society 82, 4903-4904.

EMERY, T. F. \& NeIlands, J. B. (1962). Further observations concerning the periodic acid oxidation of hydroxylamine derivatives. Journal of Organic Chemistry 27, 1075-1076.

Estep, M., Armstrong, J. E. \& Van BaAlen, C. (1975). Evidence for the occurrence of specific iron (III)-binding compounds in near-shore marine ecosystems. Applied Microbiology 30, 186-188.

FogG, G. E., Nalewajko, C. \& Watt, W. D. (1965). Extracellular products of phytoplankton photosynthesis. Proceedings of the Royal Society B162, 517-534.

Gibson, F. \& Magrath, D. I. (1969). The isolation and characterization of a hydroxamic acid (aerobactin) formed by Aerobacter aerogenes 62-1. Biochimica et biophysica acta 192, 175-181.

GOLDBERG, E. D. (1952). Iron assimilation by marine diatoms. Biological Bulletin 102, 243-248.

HARVEY, H. W. (1937). The supply of iron to diatoms. Journal of the Marine Biological Association of the United Kingdom 22, 205-219.

Hellebust, J. A. (1974). Extracellular products. In Algal Physiology and Biochemistry, pp. 167-202. Edited by W. D. P. Stewart. Berkeley, California: University of California Press.

Hood, W., Leaver, A. G. \& Carr, N. G. (1969). Extracellular nitrogen and the control of arginine biosynthesis in Anabaena variabilis. Biochemical Journal 114, 12-13.

Hutner, S. H. (1972). Inorganic nutrition. Annual Review of Microbiology 26, 313-346.
Kratz, W. A. \& Myers, J. (1955). Nutrition and growth of several blue-green algae. American Journal of Botany 42, 282-287.

Kurowski, W. M. \& PIRT, S. J. (1971). The iron requirement of Agrobacterium tumefaciens for growth and 3-ketosucrose production. The removal of iron from solutions by Seitz filters. Journal of General Microbiology 68, 6569.

LANKFORD, C. E. (1973). Bacterial assimilation of iron. CRC Critical Reviews in Microbiology 2, 273-311.

LANKFord, C. E., WALKeR, J. R., ReEves, J. B., NABbUT, N. H., BYers, R. B. \& Jones, R. J. (1966). Inoculum-dependent division lag of Bacillus and its relation to an endogenous factor(s) ('schizokinen'). Journal of Bacteriology 91, 10701079.

Macham, L. P. \& Ratledge, C. (1975). A new group of water-soluble iron-binding compounds from mycobacteria: the exochelins. Journal of General Microbiology 89, 379-382.

MaCKInNey, G. (1941). Absorption of light by chlorophyll solutions Journal of Biological Chemistry 140, 315-322.

Morgan, J. C. (1975). Master's thesis, The University of Texas at Austin, U.S.A.

Murphy, T. O., Lean, D. R. S. \& Nalewajko, C. (1976). Blue-green algae: their excretion of ironselective chelators enables them to dominate other algae. Science 192, 900-902.

MYERS, J. (1950). The culture of algae for physiological research. In The Culturing of Algae, pp. 4551. Edited by J. Brunel, G. W. Prescott \& L. N. Tiffany. Yellow Springs, Ohio: The Charles F. Kettering Foundation.

NEILANDS, J. B. (1966). Naturally occurring nonporphyrin iron compounds. Structure and Bonding 1, 59-108.

NeILANDS, J. B. (1973). Microbial iron transport compounds (siderochromes). In Inorganic Biochemistry, vol. I, pp. 2-34. Edited by J. B. Neilands. New York: Academic Press.

Provasoli, L., Mclaughlin, J. J. A. \& Droop, M. R. (1957). The development of artificial media for marine algae. Archiv für Mikrobiologie 25, 392-428.

Simpson, F. B. \& Neilands, J. B. (1976). Siderochromes in Cyanophyceae: isolation and characterization of schizokinen from Anabaena sp. Journal of Phycology 12, 44-48

SNow, G. A. (1965). The structure of mycobactin P, a growth factor for Mycobacterium johnei, and the significance of its iron complex. Biochemical Journal 94, 160-165.

STOoKey, L. L. (1970). Ferrozine-a new spectrophotometric reagent for iron. Analytical Chemistry 42, 779-781.

VAN BaAlen, C. (1962). Studies on marine bluegreen algae. Botanica marina 4, 129-139. 
VAN BAALEN, C. (1965). Quantitative surface plating of coccoid blue-green algae. Journal of Phycology 1, 19-22.

Van BaAlen, C. (1967) Further observations on the growth of single cells of coccoid blue-green algae. Journal of Phycology 3, 154-157.
WALBSY, A. E. (1974). The extracellular products of Anabaena cylindrica Lemm.I. Isolation of a macromolecular pigment-peptide complex and other components. British Phycological Journal 9, 371381. 